\title{
O RECONHECIMENTO DO IMIGRANTE COMO SUJEITO DE DIREITOS HUMANOS NA NOVA LEI DE MIGRAÇÃO BRASILEIRA.
}

Elaine Dupas ${ }^{1}$

\section{Resumo:}

A Lei de Migração confere nova perspectiva à política migratória brasileira por conceder direitos ao imigrante internacional. O revogado Estatuto do Estrangeiro era incompatível com a Constituição Federal de 1988. O objetivo é analisar se a lei que que prevê o imigrante como sujeito de Direitos Humanos, é capaz, isoladamente, de alterar a realidade social. Desenvolver-se-á o objetivo por meio de exposição de breve histórico da migração no Brasil, análise da lei e, por fim, por meio de análise sociológica, utizando Abdelmalek Sayad e Axel Honneth como marcos teóricos. A pesquisa é exploratória e bibliográfica por meio de análise hermenêutica.

\section{Palavras-chave:}

Direitos Humanos; Lei de Migração; Imigrante Internacional.

\section{THE RECOGNITION OF THE IMMIGRANT AS A SUBJECT OF HUMAN RIGHTS IN THE NEW LAW OF BRAZILIAN MIGRATION.}

Abstract:

The Migration Law confers a new perspective on the Brazilian immigration policy for granting rights to the international immigrant. The revoked Foreigner Statute was incompatible with the Federal Constitution of 1988. The objective is to analyze if the law that foresees the immigrant as subject of Human Rights, is capable of, alone, of altering the social reality. The objective will be developed through a brief history of migration in Brazil, analysis of the law and, finally, through sociological analysis, using Abdelmalek Sayad and Axel Honneth as theoretical frameworks. The research is exploratory and bibliographical through hermeneutical analysis.

Key words:

Human rights; Law of Migration; International Immigrant.

\section{INTRODUÇÃO}

\footnotetext{
1 *Doutoranda em Direito do Estado no curso de Doutorado Interinstitucional (Dinter USP/UFMS) em Direito da Universidade de São Paulo (USP) e Universidade Federal de Mato Grosso do Sul (UFMS). Mestra em Fronteiras e Direitos Humanos no programa de pós-graduação stricto sensu da Faculdade de Direito e Relações Internacionais da UFGD (Universidade Federal da Grande Dourados). Graduanda em Ciências Sociais na Universidade Federal de Mato Grosso do Sul (UFMS). Advogada. E-mail: elaine.dupas@gmail.com
} 
A Lei de Migração, lei n. 13.445, de 24 de maio de 2017, que inaugura uma profunda transformação na legislação brasileira, concedendo aos imigrantes o status de sujeitos de direitos humanos, será abordada sob a perspectiva sociológica de Abdelmalek Sayad que trata a migração como fato social completo e com referência na Teoria do Reconhecimento de Axel Honneth que coloca determinado grupo social como protagonista da luta moralmente motivada para o reconhecimento de sua existência como cidadão.

O Estatuto do Estrangeiro, lei n. 6.815, de 10 de agosto de 1980, foi revogado após vários anos de críticas e incompatibilidades com a Constituição Federal de 1988 e com os Tratados Internacionais de Direitos Humanos, visto que tinha o imigrante como ameaça à nação e como princípio máximo a soberania e segurança nacional, reafirmando a história de décadas de exclusão e utilitarismo econômico dos estrangeiros (termo não mais utilizado pela atual lei) que vieram para o Brasil.

Não é possível tratar da Lei de Migração sem abordar o impacto que tem na vida dos imigrantes, reconhecer e identificar quem são os agentes afetados pela alteração legislativa é de extrema relevância para a compreensão da efetividade legal. Afinal, até então eram denominados estrangeiros, demonstrando o caráter segregador da antiga legislação e das anteriores ao Estatuto que possuem reflexos do pensamento eugenista e fortaleciam os estigmas relacionados aos que vinham de outros países em busca de oportunidades no Brasil.

O objetivo geral do presente artigo é abordar a nova lei de migração sob a perspectiva sociológica de Abdelmalek Sayad e correlacionar com a Teoria do Reconhecimento de Axel Honneth para averiguação da possibilidade da lei ser instrumento jurídico de reconhecimento do imigrante como sujeito de Direitos Humanos.

Portanto, há que se traçar minimamente o histórico migratório brasileiro para compreender como o imigrante internacional foi visto pelo Estado e como a alteração legislativa fornece esperança de reconhecimento dos imigrantes como cidadãos.

Para alcançar tal objetivo, serão desenvolvidos os seguinte objetivos específicos: traçar um breve histórico do perfil legislativo sobre política migratória no Brasil, por meio da percepção social em relação ao imigrante; analisar os princípios norteadores da atual legislação que pela primeira vez reconhece os imigrantes como 
sujeito de Direitos Humanos; e, por fim, correlacionar com as teorias sociológicas adotadas como referenciais teóricos para o desenvolvimento da análise proposta.

A metodologia utilizada, quanto aos fins, foi realizada de maneira exploratória e descritiva, tendo em vista o objetivo de se demonstrar a possibilidade da nova Lei de Migração ser instrumento jurídico de reconhecimento efetivo do imigrante como sujeito de Direitos Humanos, utilizando-se, para tanto, o método dedutivo. E, quanto aos meios, a pesquisa é bibliográfica, foram coletados materiais a partir de livros, artigos científicos, legislações nacionais e internacionais, dissertações, teses de doutorado e relatórios de organizações internacionais.

1. Imigração no Brasil: acúmulo de violações de direitos e construções de estigmas sociais

A história do Brasil poderia ser contada sob a perspectiva da imigração internacional. Afinal, tal fato social faz parte do histórico de colonização até os dias atuais, alternando apenas quem vem e por qual motivo entra em território nacional.

Jeffrey Lesser (2015) inaugura sua obra “A invenção da brasilidade” com o capítulo "Criando brasileiros: imigração e identidade nacional", tal título retrata com genialidade a concepção de formação do Brasil pelos imigrantes e a importância dos mesmos para a nação. Porém, a história demonstra que nem sempre foram concedidos direitos a eles e estiveram à margem social, realmente sendo considerados os que não pertenciam à nação, conforme será demonstrado pela legislação, e explicado por Sayad (1998) como será analisado.

Há que se ressaltar que o Brasil sempre utilizou o imigrante para seus interesses, assim como afirma Lesser (2015):

No Brasil, entretanto, a relação entre imigração e identidade nacional é outra. Intelectuais, políticos, assim como lideranças culturais e econômicas, viam (e ainda veem) os imigrantes como agentes do aperfeiçoamento de uma nação imperfeita, conspurcada pela história do colonialismo português e pela escravidão afriacana. Como resultado, os imigrantes muitas vezes foram saudados como salvadores que trouxeram mudanças e melhorias ao Brasil, e não por terem melhorado graças ao Brasil. (LESSER, 2015, p. 28)

Há, portanto, o indicativo do princípio do utilitarismo econômico que norteia do Estatuto do Estrangeiro. Porém, tal princípio não é novidade do período ditatorial, 
como geralmente é afirmado. Essa postura de utilizar o imigrante para interesses da nação marca toda a história imigratória do país. Será tratado com maior ênfase ao analisar o Estatuto revogado.

A abolição da escravidão é marco histórico para o estudo da imigração no Brasil. Até então, o perfil do imigrante era relacionado às necessidades de colonização e povoamento. Já em 1988, com o fim do tráfico negreiro datado de 1850, a necessidade é associada à mão-de-obra.

Nesse sentido, afirma Oliveira que "é o fim do tráfico negreiro que começa a colocar na ordem do dia a necessidade de substituição de mão-de-obra por imigrantes." (OLIVEIRA, 2000, p. 14). E Carneiro (2005) enfatiza que a situação do negro escravizado não muda devido ao fim do tráfico negreiro, abolição e por conta dessa necessidade de força de trabalho, afinal "dos porões dos navios negreiros esses homens passaram para os porões da sociedade" (CARNEIRO, 2005, p. 15-16)

Segundo Dupas (2018), “a entrada de imigrantes no século XIX acontece com dois focos: ocupar pequenas propriedades agrícolas e, posteriormente, trabalhar nas lavouras de café." Sempre atendendo aos interesses da nação. E completa afirmando que “a relação do Brasil com a imigração, historicamente, teve o caráter de utilizar o imigrante para determinado fim, seja para colonizar, para mão-de-obra, para os projetos de branqueamento e modernização.” (DUPAS, 2018, p.51-52)

O Brasil, nesse período, estava em processo de industrialização, e o trabalho escravo era custoso e tido como ultrapassado.

Sobre a entrada de imigrantes após a abolição da escravidão, ressalta-se:

Entre 1887 e 1930, de acordo com Boris Fausto (1995), entraram no Brasil cerca de 3,8 milhões de estrangeiros. Sendo que no período de 1887 a 1914 ocorreu o maior número de entradas no país, o equivalente a $72 \%$ do total. Justifica-se pela necessidade de força de trabalho para a lavoura de café. Entretanto, com a Primeira Guerra Mundial, há uma significativa redução do fluxo, que é retomado após o final do conflito bélico em 1918, momento no qual se inicia uma nova onda migratória que vai até 1930. (DUPAS, 2018, p. 53)

Logo, havia a ideia de que o imigrante era superior ao negro em relação a força e qualidade de trabalho, porém, não era equiparado ao cidadão nacional.

Nesse período também era reforçada a ideia de branqueamento da nação. E os imigrantes seriam os protagonistas desse projeto de transformação física do brasileiro. 
A miscigenação seria necessária para branquear a população, e, portanto, a legislação se torna mais atraente com permissões que demonstravam que o Brasil era um país atraente para o destino dos imigrantes.

A imigração é "a nova mística do progresso" nesse contexto de modernização e branqueamento do país (LESSER, 2015, p. 29). E, portanto, segundo Dupas:

Tem-se um outro perfil imigratório específico desse período histórico, os imigrantes que buscam oportunidades de trabalho e de ascensão social em uma nova nação por meio da aquisição de terras. E em contrapartida, o Estado busca o imigrante apto para as atividades agrícolas e que seja branco, pois assim a população se tornará homogênea em algumas gerações. Essa questão permeará todo o estudo aqui presente, o pensamento eugênico tem forte influência em todo fenômeno imigratório ocorrido no Brasil. (DUPAS, 2018, p.55)

O estigma que era atribuído ao negro escravizado passa a ser atribuído também ao imigrante, pois são colocados no mesmo patamar social que que aqueles, além disso, havia o pensamento eugenista que reforçava todos os estigmas atribuídos a estes grupos.

Havia o incentivo para a entrada, porém, também a proibição por meio da legislação que limitava ou/e proibia a entrada de imigrantes africanos e também os asiáticos. O controle era realizado pelos diplomatas e pela polícia no ponto de embarque ou nos portos brasileiros. (LESSER, 2015, p. 61)

Para ilustrar tal realidade, é possível mencionar a oposição aos imigrantes negros. Afrânio Peixoto realizava estudos pautados na medicina e criminologia e escrevia na época que:

"É neste momento em que a América pretende desembaraçar-se de seu núcleo de 15 milhões de negros no Brasil (...) Quantos séculos será preciso para depurarmos todo esse mascavo humano? Teremos albumina bastante para refinar toda essa escória? Quanto tempo ainda tem para a redenção de Caim? Não bastou a Libéria! Descobriram o Brasil (...) Pois bem, ainda com as armas na mão, não, não e não. Deus nos acuda se é brasileiro! (PEIXOTO, 1938, p.69)

A legislação era marcada pelo pensamento eugenista, que tinha a finalidade do melhoramento da raça humana considerando a raça branca superior, principalmente na Era Vargas (1930 - 1945), sendo uma norma racista que refletia a tendência de exclusão defendida por teóricos que se utilizavam de critérios ditos científicos para 
justificar os problemas da imigração. Ou seja, o imigrante era o responsável pelos problemas sociais do país. Logo, a imigração era o problema e a solução para os problemas do Brasil.

Cunha afirma sobre a aplicação do pensamento eugenista para a solução dos problemas nacionais:

Pobreza, incultura, criminalidade, barbárie, insalubridade, entre outros descaminhos na não-adaptação dos homens à vida social, devem ser reconduzidos pelo consórcio que a medicina e o direito empreendem, visando à construção da nação. Uma vez eregida sobre as diferenças biologicamente conhecidas, a igualdade legal pode ser postulada. (1999, p. 280) (grifos nossos)

E Carneiro complementa:

Em nome da civilização e do progresso material, a pobreza deveria ser evitada assim como as doutrinas exóticas e a diversidade étnica. O equilíbrio social, racial e político só seria alcançado por meio da intervenção direta do Estado [...]. Não interessava receber ou manter entre nós elementos provocadores da desagregação social, da heterogeneidade racial e da desordem política. (CARNEIRO, 2010, p. 48)

Na concepção dos teóricos da época, ao melhorar a raça, estaria melhorando a composição social. A teoria eugenista afirmava que: "sanando a sociedade de pessoas que tinham características que eram consideradas indesejáveis, tais como doenças mentais que propiciavam impulsos criminosos, como era propagada pelos intelectuais de pensamento eugenista". (MACIEL, 1999, p. 121).

Logo, fica demonstrado que a ideia de exclusão do imigrante não é a partir da Ditadura Militar e do Estatuto do Estrangeiro. Essa sempre foi uma postura adotada pelo Estado. Os princípios de segurança nacional e utilitarismo econômico sempre estiveram presente nas legislações relacionadas à política migratória.

Ressalta-se que o mencionado Estatuto é um compilado organizado das legislações anteriores, já que as normativas eram fragmentadas e desorganizadas. (CAHALI, 1983, p. 74)

O problema toma outra proporção após a Constituição de 1988, uma vez que torna o Estatuto incompatível com o texto constitucional que é baseado na dignidade da pessoa humana e também em desacordo com os tratados internacionais de Direitos Humanos. 
O Estatuto era norteado pelos princípios contidos no “Art. 2o Na aplicação desta Lei atender-se-á precipuamente à segurança nacional, à organização institucional, aos interesses políticos, sócio-econômicos e culturais do Brasil, bem assim à defesa do trabalhador nacional.” (BRASIL, 1980, grifos nossos)

Princípios estes que geram uma insegurança jurídica a respeito do tema e que, de acordo com Dupas (2017), cabe ao aplicador da lei a verificação das necessidades nacionais para atender os interesses do país

Logo, se fazia urgente uma nova legislação que acompanhasse as mudanças trazidas pela Constituição Federal e que reformulasse a maneira como o imigrante internacional era visto pelo Estado brasileiro.

2. Lei de Migração: o reconhecimento na esfera jurídica do imigrante como sujeito de Direitos Humanos

Conforme analisado, as legislações sempre trataram o imigrante internacional como ameaça e como algo externo à população, sendo estigmatizado pelo próprio Estado. Regidas pelos princípios do utilitarismo econômico e segurança nacional, as legislações até então não se preocupavam com a garantia de direitos para os imigrantes internacionais. Regulavam a política migratória sem considerar o fator humano digno de proteção.

A Nova Lei de Migração rompe com esse passado de segregação que buscava no imigrante a solução de problemas nacionais como a colonização, povoamento e mãode-obra e passa a tratar do ser humano envolvido no processo migratório, inaugura o olhar estatal pra o sujeito que migra. Essa é a grande novidade legislativa: o reconhecimento legislativo do imigrante internacional como sujeito de Direitos Humanos.

Em contrapartida, o decreto regulamentador, Decreto 9.199, de 20 de novembro de 2019, impossibilitou a aplicação efetiva da legislação. Na verdade, o decreto vai de encontro, chocando-se com o espírito da lei de migração. Tal decreto burocratizou os procedimentos migratórios, e, novamente, tornou a legislação sobre política migratória esparsa e fragmentada, fato esse severamente criticado em relação ao revogado Estatuto do Estrangeiro. 
Porém, o objetivo do presente artigo não é analisar a efetividade da lei de migração e a viabilidade do decreto regulamentador, por esse motivo não será abordado com maior profundidade. Objetiva-se, porém, a análise das modificações do Estado em relação ao imigrante internacional por meio do instrumento jurídico, ou seja, a lei 13.445 de 27 de maio de 2017.

Dentre as novidades e modificações em relação aos imigrantes, destacam-se: a acolhida humanitária, a não criminalização da migração, ampliação das espécies de vistos, e mudança de terminologia, desburocratização e flexibilização das condições para acordos de reciprocidade para a isenção de visto de visita, e, principalmente, a mudança principiológica que norteia a lei, e que é objeto de da análise sociológica proposta nesse artigo.

Essas modificações permitem que o imigrante seja reconhecido pelo Estado como sujeito de Direitos Humanos na esfera jurídica, o que não garante que as condições de vida de tais seres humanos que migram, sejam alteradas na prática. E será explicado no próximo tópico os motivos sociológicos que fazem com que os estigmas permaneçam latentes na sociedade.

Em relação aos princípios, a letra do artigo terceiro da lei de Migração traz um extenso avanço principiológico ao determinar que "a política migratória brasileira rege-se pelos seguintes princípios e diretrizes, dos quais destaca-se:

universalidade, indivisibilidade e interdependência dos direitos humanos; repúdio e prevenção à xenofobia, ao racismo e a quaisquer formas de discriminação; não criminalização da migração; acolhida humanitária; inclusão social, laboral e produtiva do migrante por meio de políticas públicas; repúdio a práticas de expulsão ou de deportação coletivas. (BRASIL, 2017)

Há, mediante tais princípios, a compatibilização com a Constituição Federal e respeito à dignidade humana que norteia o Estado Democrático de Direito. E, diante de tal adequação, afirma Honneth que é "pela concessão social desses direitos, é possível medir se um sujeito pode conceber-se como membro completamente aceito de sua coletividade", ou seja, se tal sujeito é pertencente na sociedade como cidadão. (HONNETH, 2003, p. 69)

Nesse sentido, afirma Dupas (2017):

Ou seja, a sociedade brasileira não perde direitos e garantias ao conferir direitos constitucionais aos imigrantes. E essa percepção social só é 
alcançada pela esfera jurídica, e, posteriormente, pela esfera da estima social, na qual os direitos saem da previsão formal e alcançam a materialidade. (ELIAS; SCOTSON, 2000; HONNETH, 2003 apud DUPAS, 2017, p.106)

A acolhida humanitária, elencada como uma das principais mudanças, deixa de ser apenas garantida em resolução normativa por meio do visto humanitário introduzido para conter um problema emergencial de pedidos de refúgios por haitianos em 2010 e com o objetivo de controlar situações emergenciais, que começou a ser concedido no país em caráter emergencial por meio da Resolução Normativa n.o 97, de 12 de janeiro de 2012, do Conselho Nacional de Imigração (CNIg). (SILVA, 2015)

Com a nova legislação, a previsão de acolhida humanitária passa integrar o corpo textual da lei, perde o caráter de precariedade. Tal previsão estar contida em lei é essencial para o reconhecimento do imigrante como sujeito detentor de tal garantia e para que a população passa a conceber o outro como detentor de direitos.

Nesse sentido, Dupas afirma que "a nova lei de migração faz previsão da acolhida humanitária, sendo agora então previsto em lei e não mais apenas em resolução normativa. Aumentando as possibilidades de concessão de visto, e afastando a precariedade.” (DUPAS, 2017, p.107)

O combate à discriminação é outra alteração legislativa de relevância para garantir os direitos e prevenir as violações de Direitos Humanos que sofrem os imigrantes. A lei prevê repúdio a qualquer forma de discriminação. A não criminalização, além da inovação no caráter penal de não privar ninguém de sua liberdade por razões migratórias, também é uma forma de prevenção da discriminação que, geralmente, é demonstrada por meio de ações xenófobas, como afirma Dupas:

Logo, na luta pelo reconhecimento, o combate à discriminação é indispensável. Criminalizar a xenofobia e combater qualquer forma de discriminação é fundamental para o reconhecimento do imigrante como sujeito de direitos. Afinal, o desrespeito com a nacionalidade fere a dignidade da pessoa humana. (DUPAS, 2017, p. 110)

Parreira e Berner afirmam:

O outro não está mais em um lugar distante e desconhecido para nós, e sim, logo ao lado. Nesse caso, somos confrontados diretamente com o desconhecido que acaba virando bode expiatório de todos os nossos problemas. Eles são considerados os inimigos que devem ser evitados, segregados e deportados. Não se procura adaptá-los à nova realidade, 
acolhê-los. Na verdade, o que se busca é somente fechar as fronteiras, impedindo uma "invasão estrangeira". (2016, p. 244)

Portanto, a previsão do combate à discriminação e da não criminalização da migração faz com que a sociedade tenha uma outra percepção sobre os imigrantes internacionais e altere os estigmas, o que será explicado no próximo tópico por meio da Teoria do Reconhecimento de Axel Honneth, a qual prevê a esfera jurídica como forma de reconhecimento de direitos diante da sociedade e da percepção de ser portador de tais direitos conquistados.

Percebe-se, portanto, que a lei de migração objetiva a garantia dos Direitos Humanos ao tratar da temática pelo viés de concessão de direitos aos imigrantes e por ser norteada por princípios que visam a dignidade do sujeito.

A mudança legislativa, isolada, não é capaz de alterar a realidade social. Logo, a compreensão dos impactos sociais se dá por meio da análise sociológica que visa conceituar quem é o imigrante e como ele é visto pela nova sociedade que o recebe, porém, não o assimila socialmente em todas as esferas. Ou seja, compreender quem é o sujeito que migra, a partir da percepção do imigrante, e como a sociedade o reconhece a partir dos direitos que são garantidos.

3. Lei de Migração e o imigrante internacional sob a perspectiva sociológica de Abdelmalek Sayad e Axel Honneth.

A lei de migração atual, conforme breve histórico exposto sobre a utilização dos princípios do utilitarismo econômico e segurança nacional, rompe com o histórico de legislações violadoras dos Direitos Humanos. O Brasil sempre escolheu, e ainda o faz, qual imigrante era/é o ideal para adentrar o território nacional e tal decisão é regulada pelas normativas referentes ao tema.

Compreender quem é o imigrante e porque ele migra é essencial para entender a migração como fato social completo, como proposto por Abdelmalek Sayad (1998) que enfatiza que antes de ser imigrante em uma nação, o sujeito é emigrante em outro país, ou seja, ela inaugura a análise do fenômeno migratório por focar no sujeito.

E após a compreensão de quem é o imigrante, será discutido, por meio da análise da Teoria do Reconhecimento de Axel Honneth (2003), como este sujeito que 
vem de fora é reconhecido na sociedade receptora, e de que forma este "outro" não pertencente passa a fazer parte do corpo social e alcança a status de cidadão.

Sayad (1998) parte do conceito que a migração é um fato social completo. Segundo Durkheim, o fato social tem características específicas, quais sejam: generalidade, exterioridade e coercitividade, que produzem formas de sentir, pensar e agir, construindo e impondo valores morais, crenças, normas, doutrinas. (DURKHEIM, 2007)

Trata o itinerário do imigrante como o próprio processo para tornar-se imigrante e que suas vivências e trajeto corresponde à interligação das ciências sociais de maneira epistemológica, ou seja, há o encontro com várias “disciplinas como a história, geografia, demografia, economia, direito, sociologia, psicologia e psicologia social e até mesmo as ciências cognitivas, antropologia em duas diversas formas [...] ciência política e etc.” (SAYAD, 1998, p. 15)

Para Sayad (1998) os saberes das diversas ciências que permeiam o fenômeno da migração são construídos e vão se interligando durante sua trajetória até seu destino, formando o fato social completo.

A migração ocorre para solucionar uma demanda por mão-de-obra, porém, torna-se um problema social no país receptor. Essa talvez seja uma das principais características apontadas por Sayad (1988) que caracteriza a fenômeno migratório: a provisoriedade.

Portanto, o imigrante sempre será visto pela sociedade como uma presença passageira que adentrou o país para resolver um problema de mão-de-obra. E mesmo que permaneça por anos, a caráter de provisoriedade o acompanha. Bem como, afirma que sempre há a intenção de voltar para sua terra natal, mesmo que tal desejo nunca se concretize. (SAYAD, 1998)

Esse caráter de provisoriedade faz com que a presença do imigrante seja tolerada socialmente e não aceita como algo definitivo, e, portanto, não há o "direito de uma presença reconhecida como permanente" e completa afirmando que "como se esse provisório pudesse ser definitivo ou pudesse se prolongar de maneira indeterminada". (SAYAD, 1998).

É inegável que o imigrante é importante para a sociedade que o recebe, afinal, como dito, este migra com finalidade de suprir a demanda por mão-de-obra, além de ser 
relevante para a demografia local. Logo, é perceptível a utilidade econômica do imigrante para a sociedade, mas mesmo assim ele é estigmatizado e taxado de "parasitas e ao estimar que não se deve nada a eles, se deplore o custo social elevado que sua presença impõe à sociedade". (SAYAD, 1998, p. 47)

E ainda seguindo lógica de ser relevante para a sociedade, mas de seu valor não ser reconhecido, Sayad (1998) afirma que dessa contradição nasce a equação da migração, a qual busca equilibrar os "custos e vantagens" da presença do imigrante na sociedade e que tal equação é a base da teoria econômica migracional que é considerada tendenciosa porque sempre é realizada pela sociedade receptora. (SAYAD, 1988, p. 4447)

Nesse sentido, explica Dupas:

Logo, Sayad afirma que toda a história da imigração carrega a intenção de maximizar as vantagens e reduzir ao mínimo os custos. Sendo então a formulação reveladora da função objetiva e, secreta, como enfatizado pelo autor, aplicada aos imigrantes e que variará segundo as necessidades do momento.

E tal equação pode ser considerada uma definição da imigração e dos imigrantes, uma vez que é a soma do trabalho jurídico, afinal direitos são reconhecidos aos imigrantes; do trabalho político, pois há acordos entre as nações para definição de forma de entrada, condições de trabalho e etc, e; por fim, do trabalho social, por meio de ações diversas que visam a melhor adaptação da população imigrante. (DUPAS, 2018, p. 20)

Nasce a contradição da migração diante da equação que busca equilibrar os custos e vantagens, afinal, se de um lado há a importância do imigrante para a sociedade, do outro há a tentativa de proporcionar o mínimo para que tenham seus direitos materiais atendidos. E, segundo Sayad, a legislação sobre política migratória é construída com base nesse jogo de custos e vantagens, ou seja, de garantir o mínimo para que haja o máximo de vantagem com o menor custo. (SAYAD, 1998, p. 53-54)

E na tentativa de compreender quem é o imigrante e conceituar tal sujeito, Sayad (1998) responde a pergunta de quem é o imigrante com a seguinte explicação:

Um imigrante é essencialmente uma força de trabalho, e uma força de trabalho provisória, temporária, em trânsito. [...] A estadia autorizada ao imigrante está inteiramente sujeita ao trabalho, única razão de ser que lhe é reconhecida: ser como imigrante, primeiro, mas também como homem - sua qualidade de homem estando subordinada a sua condição de imigrante. (1998, p. 54-55) 
Ou seja, demonstra o caráter de coisificação, reafirmando a relação do imigrante com a mão-de-obra necessária para a nação receptora e negando sua humanidade para além da sua utilidade econômica. Há que recordar a relação ocorrida no Brasil após a abolição da escravidão, conforme mencionado no tópico introdutório, momento no qual os imigrantes foram estigmatizados da mesma maneira que os negros escravizados carregavam o peso de ter suas existências intrinsicamente relacionadas com a sua força de trabalho e apenas isso, sendo negados como seres humanos e tidos como coisas.

Também é possível relacionar o conceito de imigrante de Sayad (1998) com o temor que os nacionais têm em perderem seus empregos para a mão-de-obra imigrante. Em momentos de crise, como está o Brasil desde a aprovação da nova lei, pensamentos assim ganham força na sociedade e são tidos como uma ameaça real, reforçando o preconceito e a hostilidade com os não nacionais.

Ainda relacionado a força de trabalho, Sayad (1998) afirma que ser um imigrante desempregado é um paradoxo. Afinal, sua presença só é justificada e tolerada provisoriamente para que seja mão-de-obra. Qualquer situação que fuja dessa lógica, gera um problema social, tal como "os imigrantes e o emprego ou os imigrantes e o desemprego, os imigrantes e a habitação, os imigrantes e a formação, os imigrantes ou os filhos dos imigrantes e a escola, os imigrantes e o direito de voto (...)”. (SAYAD, 1998, p. 56)

E isto faz com que a migração seja também pensada como um problema social e que os estigmas sejam perpetuados socialmente quando a equação custos e vantagens está desregulada, fazendo com o que imigrante fique marginalizado socialmente.

Portanto, há que se compreender como se dá a possibilidade de reconhecimento do imigrante como sujeito de direitos e cidadão no país receptor. Afinal, como foi dito, sua presença é relacionada ao trabalho em caráter provisório e há uma equação que busca os custos e vantagens da permanência do imigrante na sociedade.

A Teoria do Reconhecimento de Axel Honneth será utilizada para demonstrar a construção necessária para que um grupo, historicamente excluído, seja reconhecido como portador de direitos. Afinal, o Direito não pode permitir que pessoas sejam tratadas de maneira desigual, excluindo assim a participação social de determinados grupos em função do seu status. 
Honneth afirma que para ter um direito reconhecido, é necessário que o outro o reconheça, ou seja, apenas o autorreconhecimento não é suficiente. Justifica-se a escolha por essa teoria para tal análise proposta neste artigo justamente para demonstrar que a legislação isolada, somente a esfera jurídica, não é capaz de tornar ninguém, efetivamente, portador de direitos.

Assim vejamos a explicação de Miranda:

[...] um processo intersubjetivo de luta por reconhecimento, que apresenta como núcleo estrutural as intermináveis disputas por aceitação de diferentes pretensões identitárias. Estas envolvem tanto características individuais, contextualmente específicas, quanto o respeito solidário, institucionalizado através das normas do direito positivo. (2011, p. 137)

Três esferas distintas, porém simultâneas, possibilitam o desenvolvimento do reconhecimento proposto por Honneth, são elas: amor ou amizade nas relações primárias; direitos nas relações jurídicas; e solidariedade e estima na comunidade de valores. $E$ quando há falta de reconhecimento em algumas dessas esferas, Honneth (2003), denomina de desrespeito e injustiça. O que também pode ser relacionado com a situação jurídica histórica dos imigrantes internacionais diante da legislação e sociedade brasileira.

De acordo com Dupas (2018), "dentre as formas de desrespeito que impossibilitam a concretização do reconhecimento, Honneth elenca os maus-tratos e violação, privação de direitos e degradação. Cada uma dessas perspectivas de desrespeito atinge uma das esferas de reconhecimento." (2018, p.24)

Não será tratada, neste artigo, a esfera do amor e amizade, bem como não será aprofundada a esfera da solidariedade. Afinal, o objetivo é demonstrar que a legislação afastada do fator social e da análise sociológica não confere direitos por imposição legal. Os direitos devem ser reconhecidos socialmente para terem validade e efetividade social, e esse reconhecimento deve extrapolar a esfera jurídica, necessita da participação da sociedade.

Portanto, em relação ao padrão jurídico, deve-se compreender que:

(...) só podemos chegar a uma compreensão de nós mesmos como portadores de direitos quando possuímos, inversamente, um saber sobre quais obrigações temos de observar em face do respectivo outro: apenas da perspectiva normativa de um "outro generalizado", que já nos ensina a reconhecer os outros membros da coletividade como portadores de direitos, nós podemos nos entender também como pessoa de direito, no 
sentido de que podemos estar seguros do cumprimento social de algumas de nossas pretensões. (HONNETH, 2003, p. 179)

Nesse sentido, é necessário que exista o auto reconhecimento como portador de direitos (esfera do amor e amizade - que expressam relações genuínas de afeto) para então possibilitar que o outro, por meio da esfera jurídica, reconheça tais direitos pela imposição da norma jurídica. Para então ter o reconhecimento social por meio da esfera da solidariedade ou da estima social.

Para melhor compreensão, Dupas explica:

[...] há que se considerar que quando há uma falha na esfera do amor, ou seja, nas relações genuínas que determinam o desenvolvimento psíquico do ser, afeta diretamente a possibilidade de movimentar-se socialmente para uma luta moralmente motivada, pois, muitas vezes, as classes que sofrem as injustiças e desrespeitos não se consideram aptas para serem protagonistas da busca por igualdade social. O mesmo se aplica com a esfera jurídica, não havendo o reconhecimento legal, há uma falha em todo o processo de reconhecimento social, impedindo o desenvolvimento para a esfera da estima social. (2018, p.29)

Logo, o direito do outro é reconhecido quando ele é visto como membro da sociedade. O imigrante não é tido como parte da sociedade, mas sim como presença provisória relacionada à força de trabalho. Porém, trata-se de reconhecer o outro independentemente de suas realizações ou de seu caráter, sem graduações valorativas, o que supera a ideia de que todos tem igual reconhecimento jurídico.

É por meio da esfera jurídica que um sujeito se reconhece portador de direitos e obriga-se a respeitar os direitos dos outros, pois partilham com os membros da coletividade as propriedades que o capacita para a formação discursiva da vontade. (HONNETH, 2003, p. 197)

Os estigmas acumulados por toda a história migratória brasileira fazem com que seja prejudicado o reconhecimento na esfera da estima social, uma vez que na esfera jurídica são consideradas as propriedades universais do sujeito, enquanto que na esfera da solidariedade, as propriedades individuais são priorizadas. Sendo assim, a construção dessas propriedades individuais são extremamente relevante para o contexto social.

Os estigmas relacionados aos imigrantes que são perpetuados até hoje impossibilitam que haja o reconhecimento na esfera da solidariedade. O grupo é excluído socialmente mesmo que haja reconhecimento na esfera jurídica. 
Honneth (2003) afirma que o grupo excluído socialmente trava uma luta moralmente motivada para garantir tal reconhecimento. E o que garante o reconhecimento na esfera social vai além da luta, devendo afetar a esfera pública, buscando assim elevar seu valor social.

Para um grupo ser reconhecido socialmente, este deve ter seu reconhecimento nas três esferas apresentadas por Honneth (2003): amor ou amizade; esfera jurídica; e da estima social ou solidariedade. Apenas assim há efetivamente o reconhecimento dos direitos de determinados grupos que acumulam um histórico de exclusão.

Corroborando com a Teoria do Reconhecimento, Herrera Flores afirma:

Há que se assumir o risco de romper com a cultura da "naturalização" da desigualdade e da exclusão social, que, enquanto construídos históricos, não compõem de forma inexorável o destino da humanidade. Há que se enfrentar essas amarras, mutiladoras do protagonismo, da cidadania e da dignidade de seres humanos. (2009, p. 15)

Deste modo, a luta por reconhecimento moralmente motivada, é uma forma de romper com as amarras mencionadas por Herrera Flores, é buscar a cidadania para que não haja mais violações, desrespeitos e injustiças que os imigrantes sofrem sistematicamente.

\section{Conclusões}

Por todo o exposto, conclui-se que o reconhecimento do imigrante como sujeito de Direitos Humanos, apenas na esfera jurídica, não é suficiente para garantir a efetividade e mudança real na vida de tais seres humanos que migram por diversos motivos e buscam no Brasil um recomeço.

A análise sociológica permitiu compreender o motivo da nova Lei de Migração não garantir efetivamente os direitos aos imigrantes internacionais, embora agora haja previsão legal.

O histórico de perpetuação dos estigmas atribuídos aos imigrantes e reforçado pelo Estado por meio de legislações excludentes, faz com que embora garantido juridicamente, tais direitos não sejam reconhecidos pela a sociedade receptora. Afinal, a presença do imigrante é tolerada socialmente porque há a ideia de provisoriedade relacionada com a força de trabalho que deve ter mais vantagens do que custos para a nação. 
Desse modo, há que se ter uma alteração na condição do imigrante na sociedade para que possam alcançar o reconhecimento na esfera da estima social, o grupo deve não mais ser identificado por estigmas segregadores para que possam fazer parte da sociedade compartilhando propriedade individuais que são valorizadas.

É inegável o avanço proporcionado pela Lei de Migração na política migratória brasileira. Houve o rompimento com a inconstitucionalidade do revogado Estatuto do Estrangeiro que trazia a segurança nacional e o utilitarismo econômico como prioridades ao interesse da nação, preterindo a proteção ao imigrante, que até então era denominado estrangeiro, designando justamente a sua condição de não pertencente, de ameaça à nação.

As legislações anteriores que originaram o Estatuto do Estrangeiro tinham forte influencia do pensamento eugenista, que tinha como objetivo o aprimoramento da raça e que impulsionou o projeto de branqueamento da nação brasileira. Além disso, outro fator relevante na história migratória brasileira, refere-se ao fato do imigrante substituir a mão-de-obra dos negros escravizados. Estavam tão marginalizados quanto os negros que também carregam estigmas impedindo o seu reconhecimento na esfera da estima social até os dias atuais.

Portanto, para além da legislação é necessário que haja políticas públicos inclusivas para permitir que os imigrantes gozem plenamente dos direitos garantidos pela lei de migração, mesmo com a dificuldade trazida pelo decreto regulamentador e pelas várias normas que visam regulamentar e dar aplicabilidade à lei.

A esfera jurídica é apenas uma das etapas para o reconhecimento de direitos a grupos de acumulam histórico de violações, há que se permitir, se possível pela luta moralmente motivada, que alcancem status de cidadão. Porém, muitas vezes não conseguem ser protagonistas de sua própria luta por reconhecimento e necessitam que o Estado promova meios que possibilitem a sua inclusão social. 


\section{REFERENNCIAS}

BRASIL. Constituição da República Federativa do Brasil de 1988. Disponível em:< http://www.planalto.gov.br/ccivil_03/constituicao/constituicao.htm>. Acesso em: $10 \mathrm{abr}$. 2019.

Decreto no 9.199, de 20 de novembro de 2017. Regulamenta a Lei no 13.445, de 24 de maio de 2017, que institui a Lei de Migração. Disponível em: < 
https://www.planalto.gov.br/ccivil_03/_ato2015-2018/2017/decreto/d9199.htm> Acesso em: 10 abr. 2019.

Lei no 6.815, de 19 de agosto de 1980. Define a situação jurídica do estrangeiro no Brasil, cria o Conselho Nacional de Imigração. Disponível em: < http://www.planalto.gov.br/ccivil_03/leis/L6815impressao.htm>. Acesso em: $10 \mathrm{abr}$. 2019.

Lei. 13.445, de 24 de maio de 2017. Institui a Lei de Migração. Disponível em: < http://www.planalto.gov.br/ccivil_03/_ato2015-2018/2017/lei/L13445.htm>. Acesso em: 10 abr. 2019.

CAHALI, Yussef Said. Estatuto do Estrangeiro . São Paulo: Saraiva, 1983. 587 p.

CARNEIRO, Maria Luiza Tucci. Cidadão do mundo: o Brasil diante do Holocausto e dos judeus refugiados do nazifascismo. São Paulo: Perspectiva, 2010. 476 p.

, Maria Luiza Tucci. O Anti-semitismo na Era Vargas (1930 - 1945) : Fantasmas de uma geração. São Paulo: Brasiliense, 1988. 590 p.

, Maria Luiza Tucci. O Estado Novo, o Dops e a ideologia da segurança nacional. In: PANDOLFI, Dulce (Org.). Repensando o Estado Novo . 1. ed. São Paulo: Fundação Getúlio Vargas, 1999. cap. 17, p. 327-340.

Maria Luiza Tucci. O racismo na História do Brasil: Mito e realidade. 8. ed. São Paulo: Ática, 2003. 64 p.

COMPARATO, Fábio Konder. A afirmação histórica dos direitos humanos. São Paulo: Saraiva, 1999.

CUNHA, Olívia Maria Gomes. Sua alma em sua palma: identificando a raça e inventando a nação. In: PANDOLFI, Dulce (Org.). Repensando o Estado Novo . 1. ed. São Paulo: Fundação Getúlio Vargas, 1999. cap. 14, p. 257-288.

DAL'MAS, Ítalo. Da colonização à imigração no Brasil. 1. ed. São Paulo: Hamburg, [19--]. $162 \mathrm{p}$.

DUPAS, Elaine. Nova Lei de Migração: a possibilidade de reconhecimento do imigrante como sujeito de Direitos Humanos no Brasil . 2017. 140 f. Dissertação (Mestrado em Fronteiras e Direitos Humanos)- Faculdade de Direito e Relações Internacionais, Universidade Federal da Grande Dourados, Dourados, 2017. Disponível em: $\quad<$ http://files.ufgd.edu.br/arquivos/arquivos/78/mestradofronteiras/elaine\%20dupas\%20- \%20nova\%20lei\%20de\%20migracao\%20\%20dissertacao.pdf>. acesso em: 05 abr. 2019.

DURKHEIM, Émile. As regras do método sociológico . 3. ed. São Paulo: Martins Fontes, 2007. 165 p. 
ELIAS, Norbert; SCOTSON, John L. Os Estabelecidos e os Outsiders: sociologia das relações de poder a partir de uma pequena comunidade. (Trad: Vera Ribeiro). Rio de Janeiro: Jorge Zahar Editor, 2003.

HERRERA FLORES, Joaquín. A (Re) invenção dos direitos humanos. Florianópolis: Fundação Boiteaux, 2009. p. 232

HERRERA FLORES, Joaquín. A (Re) invenção dos direitos humanos. Florianópolis: Fundação Boiteaux, 2009. p. 232

KOIFMAN, Fábio. Imigrante ideal: O ministério da Justiça e a entrada de estrangeiros no Brasil (1941 - 1945). 1. ed. Rio de Janeiro: Civilização Brasileira, 2012. 447 p.

LESSER, Jeffrey. A invenção da brasilidade: Identidade nacional, etnicidade e políticas de imigração. 1. ed. São Paulo: Unesp, 2015. 291 p.

MACIEL, Maria Eunice de S. A Eugenia no Brasil. Revista do Programa de PósGraduação em História da Universidade Federal do Rio Grande do Sul, Porto Alegre, v. 7, n. 11, p. 121-130, jul. 1999. Disponível em: <http://www.seer.ufrgs.br/index.php/anos90/article/view/6545/3897>. Acesso em: 09 abr. 2019.

MIRANDA, Sheila Ferreira. A questão do reconhecimento: Axel Honneth e a atualização do modelo conceitual hegeliano a partir da psicologia social de George Herbert Mead. In: SPINK, MJP., FIGUEIREDO, P., and BRASILINO, J., orgs. Psicologia social e pessoalidade. Rio de Janeiro: Centro Edelstein de Pesquisas Sociais; ABRAPSO, 2011, pp. 135-145. Disponível em: < http://books.scielo.org/id/xg9wp/pdf/spink9788579820571-10.pdf>. Acesso em: 10 abr. 2019.

OLIVEIRA, Lucia Lippi. O Brasil dos imigrantes. 2. ed. Rio de Janeiro: Zahar, 2002. $73 \mathrm{p}$.

OTA, Maria Eduarda. Gênero na Teoria Crítica e nas políticas públicas: a dicotomia público-privado em perspectiva. 2014. Dissertação (Mestrado em Ciências Sociais). Pucrs, Porto Alegre, 2014.

PEIXOTO, Afrânio. Revista de Imigração e Colonização. Rio de Janeiro, Francisco Alves, 1938.

PEREIRA, Tiago Porto . Desrespeito e patologias sociais na Filosofia de Axel Honneth. Problemata - Revista Internacional de Filosofia , Paraíba, v. 7, n. 1, p. 169-191, jan. $2016 . \quad$ Disponível em: <http://periodicos.ufpb.br/index.php/problemata/article/viewFile/25336/15724>. Acesso em: 07 abr. 2019.

SAAVEDRA, Giovani Agostini; SOBOTTKA, Emil Albert. Reconhecimento e teoria crítica. Civitas , Porto Alegre, v. 8, n. 1, p. 1-166, jan. 2008. Disponível em: 
$<$ http://revistaseletronicas.pucrs.br/ojs/index.php/civitas/issue/view/311>. Acesso 10 abr. 2019.

SAYAD, Abdelmalek. A imigração ou os paradoxos da alteridade . (Trad: Cristina Murachco). São Paulo: Edusp, 1998. 299 p.

SILVA, César Augusto Silva da. A política migratória brasileira para refugiados (1998 - 2014) . 1. ed. Curitiba: Íthala, 2015. $311 \mathrm{p}$.

SOBOTTKA, Emil A. Desrespeito e luta por reconhecimento. Civitas, Porto Alegre, v. 15, n. 4, p. 686-702, dez. 2015. Disponível em: <http://repositorio.pucrs.br/dspace/bitstream/10923/8244/2/Desrespeito_e_luta_por_rec onheci mento.pdf>. Acesso em: 08 abr. 2019. 